\title{
Film Distribution and Its Discontents: A Review of Michael Kho Lim's Philippine Cinema and the Cultural Economy of Distribution
}

Elvin Amerigo Valerio

Philippine independent or "indie" cinema as we understand it today is often traced back to Kidlat Tahimik's 1977 avant-garde film Mababangong Bangungot [Perfumed Nightmare]. Written, directed, and produced by Kidlat on a miniscule budget, the film won the FIPRESCI Prize at the 1977 Berlin Film Festival and was a critical success. Its triumph at the Berlin Film Festival led to its becoming the first Filipino film to be released commercially in Germany while its international distribution rights were eventually bought by American Zoetrope, the film company founded by Francis Ford Coppola (Sorilla, 2020). While much has indeed been written about the film's achievements in Europe and the United States, few seem to highlight the fact that Mababangong Bangungot, a Filipino film, never had an actual theatrical run in the Philippines. Local critics, cineastes, and aspiring filmmakers who wished to see the film had no choice but to wait for the occasional special screening at film festivals or college campuses.

Fast-forward thirty-two years later. Independent filmmaker Brillante Mendoza became the first-and so far, only-Filipino to win the Best Director award at the Cannes Film Festival for his 2009 film Kinatay (a.k.a. The Execution of $P$ ). Isabelle Huppert, the jury president of Cannes that year, was so impressed with Kinatay that the acclaimed French actress agreed to star in Mendoza's 2012 hostage thriller Captive. But despite the film's historic win at Cannes, not to mention its more accessible linear storyline (as opposed to Mababangong Bangungot's idiosyncratic narrative), 
Kinatay only had a few special screenings in selected movie theaters in the Philippines; and much like other indie films, Kinatay's primary spectators comprised mostly of filmmakers, college students, and critics; in other words, the few loyal patrons of the local indie film scene. Looking at the fate of these two landmark films, it seemed that the approbations it received from international critics were not enough to arouse the interest of local film distributors and thus lessened its chances of reaching a wider audience.

I begin this review by foregrounding the apparent inability of Mababangong Bangungot and Kinatay to be commercially shown in Philippine movie theatres in order to underscore the absence, then and now, of an established distribution system within the indie film sector. Operating outside or within the fringes of the movie industry and presenting stories that do not necessarily conform to proven box-office formulas, indie filmmakers lack the distribution machinery of the mainstream movie industry that allows its products to be seen by a wider audience and earn substantial revenue to ensure the production of more films in the future. As such, while many indie filmmakers strive to maintain a sense of artistic integrity by making films that are personally meaningful to them, they also have to keep in mind that their work as a filmmaker should likewise be sustainable, hence the need to reach a bigger audience. This seemingly never-ending dilemma is what Michael Kho Lim interrogates in his book Philippine Cinema and the Cultural Economy of Distribution (Palgrave Macmillan, 2019).

The book is indeed, as Lim himself writes in the introduction, the first to explore film distribution within the context of the independent sector in the Philippines (pp. 1-2). A former producer for independent film productions, Lim strays from the usual study of the aesthetic nuances and/or socioartistic significance of indie films and instead brings to the fore the hitherto unaddressed yet pervasive problem of how to make independent films more accessible to Filipino audiences. As Lim observes, the primary concern of most indie filmmakers is to secure funding for their projects. Once their "labor of love" is finished and has made the rounds of local and international festivals, they are at a loss as to how to exhibit their films to the general public. With no established distribution model to subscribe to, their works quickly fade into the background and become largely unseen in their home country. Therefore, Lim asserts that "distribution" is the underlying problem because the filmmaker's twin desire for creative independence and financial sustainability are both inextricably tied to reaching more moviegoers. A wider audience promises more revenue; more revenue enables filmmakers to make more films while simultaneously maintaining their independence. However, as Lim weaves through the various issues pertaining to the 
production, distribution, exhibition, and reception of independent films, he shows us that this is easier said than done.

Lim approaches each chapter of his book with an impressive wealth of research. In chapter 2, he asserts that "distribution is an unexplored terrain, hence rather invisible, in film scholarship" (p. 11) and establishes an industry approach to film studies that focuses on the modes of production and consumption, inevitably touching on the process of distribution. Lim's survey of literature on the new and emerging study of media as industries forms the basis of his own framework comprising of a comparative approach, or one that examines distribution within the film industry level and draws comparisons on the business strategies across various institutions, and a cultural approach, which takes the discussion away from the big players to the contributions made by smaller-scale entities and less well-funded operations such as the independent film sector (p. 29). In chapters 3 and 4 , he unpacks the manifold and rather slippery constructions of the term "independent film" and locates it within the context of the history of independent cinema in the Philippines. While indie cinema has traditionally been a world unto itself (with its own array of "superstar" actors, directors, and a small but loyal following), Lim notes that in recent years the modes of production in the indie sector and the mainstream industry have overlapped and blurred the traditional boundaries between the two, resulting in what seems like a reversal of structures that Lim dubs as "mainstreaming indie" and "indiefying mainstream" (pp. 74, 82). He cites the recently established Spring Films, Origin8 Media, TBA Studios, Reality Entertainment, and Quantum Films as examples of independent film companies with a more commercial outlook and are oriented toward movies with edgier narratives but still accessible to a general audience. These companies were founded by individuals who also work in the mainstream industry (such as actor Piolo Pascual and directors Joyce Bernal and Erik Matti) or by film enthusiasts who come from wealthy families and thus possess enough capital to compete with industry players. On the other hand, major studios such as Viva Films, Regal Films, and most especially Star Cinema have diversified and created new production units that are devoted to producing less formulaic films.

Chapters 5 and 6 present how film distribution and exhibition act as "cultural intermediaries and economic actors in shaping cultural and economic values, and how these are controlled and negotiated towards the making of a film from its inception down to audience consumption" (p. 122). As he narrates the history of film distribution and exhibition in the Philippines from the stand-alone theaters of the 1950s up to the '70s to today's era of mall multiplexes, Lim argues that to simply view this system from a purely economic standpoint is to overlook and neglect the cultural 
value that is attached to a film, regardless whether it was a box-office hit or not. For instance, a non-earning film does not necessarily mean that it does not have any economic value. Its worth lies in serving other strategic purposes such as introducing new stars, experimenting with a new genre, or testing the market, which may yield future economic value (p. 122). Similarly, Lim asserts that cultural value is not just about the film's message, aesthetics, or technical quality. It is also about the filmmaker's body of work and the reputation that he builds over time that define his value as an artist.

Lim then illustrates the current system of distribution and exhibition in the Philippines that are dominated by the major studios and controlled by the giant malls and cinema multiplexes. As these are multimillion peso business entities, a film's capacity to bring in profits is the primary driving force of their operations. Since many indie films are unable to penetrate and compete in such a profit-driven environment, Lim notes that indie filmmakers and producers have resorted to alternative means of exhibition. One such example is the opening of "microcinemas" - small venues that are converted into movie theaters and serve as "indie spaces" (p. 151).

After a lengthy exposition, the next three chapters is where Lim really addresses the problems he raised in the introduction. Chapter 7 explores the new business models created by the emerging forms of distribution and exhibition via the internet. Lim sees this new terrain as the alternative to traditional movie theaters and thus offers more opportunities for indie films to have a longer shelf life and reach more viewers (though judging by today's line-up of movie streaming services, independent films still get a small share as majority of subscribers still prefer the big-budget mainstream productions). Chapter 8 , on the other hand, explores what Lim calls the "semi-formal" and "informal" approach that some indie filmmakers currently utilize in order to exhibit their films. The "semi-formal" approach includes cutting out the middleman (i.e., the distributor) and directly dealing with exhibitors, holding special screenings in colleges and universities or unconventional venues like watering holes (e.g., bars, coffee shops, etc.) and outdoor spaces, and online means of self-distribution such as creating an official website for the film or, if all else fails, uploading the film to video sharing sites such as YouTube and making it freely accessible to anyone. On the other hand, "informal" distribution refers to the thriving world of film piracy. For Lim, regardless of the fact that it is a form of theft, piracy has its value because it provides visibility and accessibility, albeit informally (p. 222). Even if a filmmaker does not earn any profit, his works are nevertheless seen by more people (usually shared via the Internet in the form of torrent files) and could potentially widen his fan base. Finally, chapter 9 foregrounds the role of the state in ensuring the creation of a sustainable environment where 
mainstream and indie cinema can equally thrive and flourish. However, Lim observes that it is the politics that take center stage in this scenario as the movie industry and the government could not come to an agreement as to what course of action is most beneficial for the development of Philippine cinema. Several members of Congress have filed numerous bills over the years supposedly meant to support the film sector, but most of these bills are still languishing and it seems that politicians only pay lip service to the film sector's plea for more government support. With this, Lim finally concludes that "the real problem of Philippine cinema lies in culture itself. Being a colonised country, there is an embedded culture of colonial mentality and indifference towards its own culture. One's own culture is not given high regard because it is viewed to be inferior" (p. 264; italics in original). He suggests that there is a need to redefine "industry" to include the missing cultural aspect of filmmaking that engages with questions of values, beliefs and priorities in a very fundamental way.

Since "colonial mentality" is the underlying reason why it is difficult to nurture a sustainable environment for independent films, Lim asserts that this could not be addressed by simply fixing the distribution or exhibition system. Instead, it should start from "changing the perspectives and mindset of distributors, exhibitors, and audience...the thrust of sustainability should be anchored on critical audience development, film literacy, and the cultivation of national identity and sense of nationalism through a sound cultural or film policy" (p. 273). In terms of instituting national policies, Lim recommends a "return-to-culture" approach that reframes the "production-driven policies to consider distribution, exhibition, and audience development as legitimate objects of film policy because these are the areas where intervention is much needed" (p. 275).

Looking at the book's lengthy list of references, the amount of research and data collected by Lim is exhaustive to say the least, which undoubtedly makes him an authority in his chosen subject. Unfortunately, the strength of this book is also its weakness as Lim has a tendency to rely too much on the works of other authors and quotes them repeatedly. While this is impressive in terms of underscoring the sheer volume of his references, it mostly foregrounds the views of those authors while Lim's own authorial "voice" seems buried and lost. As such, in light of the wealth of his references, his assertion that the Filipinos' colonial mentality is the real problem seems hardly new and revelatory as this has been pointed out frequently in the past by the likes of Bienvenido Lumbera and Nicanor Tiongson. Moreover, the commercial and critical successes of recent independent films, such as Ded Na Si Lolo [Grandpa Is Dead] (Topacio, 2009), Ang Babae sa Septic Tank [The Woman in the Septic Tank] (Rivera, 2011), Heneral Luna [General 
Luna] (Tarog, 2015) and Kita Kita [I See You] (Bernardo, 2017), seem to negate this assertion. It suggests that there is perhaps an increasing number of Filipinos who are becoming more discerning and discriminating and their choice of what film to watch is based on the film's perceived qualities and not necessarily on whether it is foreign or local or mainstream or indie.

Lim also presents his recommendations in broad strokes but neglects to provide concrete examples as to how these can be achieved. Though he makes it clear in his introduction that his primary purpose is to discuss and investigate the problems in the film distribution and exhibition system and not necessarily discover a new business model for indie filmmakers and producers (p. 2), his recommendations could have had more impact had he at least proposed some tangible plan of action. For instance, he highlights the need for a national policy that will promote film literacy and develop a critical audience. What possible programs can the government initiate in order to achieve this? Is it through education? Or perhaps subsidizing and formalizing the creation of spaces dedicated to independent films (similar to what Ferdinand Marcos did with the Manila Film Center)? Whatever these may be, suggesting palpable actions can better guide readers, researchers, scholars, and policy makers on how to address the issues raised in this book.

Nevertheless, the fact that Lim has produced a well-researched and thought-provoking book on an important yet often overlooked aspect of Philippine film studies already outweighs its shortcomings. Philippine Cinema and the Cultural Economy of Distribution is therefore highly recommended especially for researchers and scholars who are interested in studying Filipino movies from an industry standpoint. It is as if Lim has swung open the door to a new and uncharted terrain in Philippine film studies and it is, as Lim himself hopes, up to the next generation of cineastes to explore this field further and contribute more knowledge. 


\section{References}

Bernardo, S. A. (Director). (2017). Kita kita (I see you) [Motion picture]. Spring Films.

Lim, M. K. (2019). Philippine cinema and the cultural economy of distribution. Palgrave Macmillan.

Mendoza, B. (Director). (2009). Kinatay (International title: The execution of P) [Motion picture]. Centerstage Productions.

Mendoza, B. (Director). (2012). Captive [Motion picture]. Centerstage Productions.

Rivera, M. (Director). (2011). Ang babae sa septic tank (The woman in the septic tank) [Motion picture]. Quantum Films.

Sorilla, F. IV. (2020, August 19). Locarno film festival 2020 revisits Kidlat Tahimik's "Mababangong Bangungot." Philippine Tatler. https://ph.asiatatler.com/life/locarno-film-festival-2020-revisitskidlat-tahimiks- mababangong-bangungot-perfumed-nightmare-1977

Tahimik, K. (Director). (1977). Mababangong bangungot (Perfumed nightmare) [Motion picture]. Kidlat Kulog Productions.

Tarog, J. (Director). (2015). Heneral Luna (International title: Antonio Luna: Indomitable General) [Motion picture]. TBA Studios and Artikulo Uno Productions.

Topacio S. (Director). (2009). Ded na si lolo (Grandpa is dead) [Motion picture]. APT Entertainment. 


\section{Grant Support Details}

Author Contributions: All research activities and writing were done by E. A. Valerio. The author has read and agreed to the published version of the manuscript.

Funding: The author received no specific funding for this work.

Acknowledgements: The author would like to thank Mr. Alex Tamayo of Plaridel Journal for his patience and generous assistance.

Conflict of Interest: The author declares no conflict of interest.

\section{About the Author}

ELVIN AMERIGO VALERIO is a PhD Candidate in Literature at De La Salle University. His areas of research interest include film history, genre studies and the construction of gender ideologies in film. His dissertation is a study of contemporary Filipino women directors of melodramas and romantic comedies (Corresponding author: ead.valerio@gmail.com).

\section{Plaridel Open Access Policy Statement}

As a service to authors, contributors, and the community, Plaridel: A Philippine Journal of Communication, Media, and Society provides open access to all its content. To ensure that all articles are accessible to readers and researchers, these are available for viewing and download (except Early View) from the Plaridel journal website, provided that the journal is properly cited as the original source and that the downloaded content is not modified or used for commercial purposes. Plaridel, published by the University of the Philippines College of Mass Communication is licensed under Creative Commons Attribution-NonCommercial-NoDerivatives 4.0 International License (https://creativecommons.org/ licenses/by-nc-nd/4.0/legalcode).

\section{How to cite this article in APA}

Valerio, E.A., (2021). Film Distribution and its discontents: A review of Michael Kho Lim's Philippine cinema and the cultural economy of distribution. Plaridel, 18(1), 317-324. https://doi. org/10.52518/2021.18.1-05valrio 